\title{
Excursus on Method
}





\section{Chapter Eleven}

\section{Principles of Kafka Interpretation}

In interpreting Kafka, have I behaved like a man of principle? Or more like the reluctant hermeneut who declared, "Certainly I am a man of principle-at least I think I am." I hope to make this question interesting by addressing any reader reading Kafka; the word "I" in the first sentence means "any interpreter." If, in reading Kafka, I uphold principles, what are these principles and what rules do they entail?

The answer is not easy, because the scene of reading is hard to stage. If I am engaged in interpreting a work by Kafka, I cannot easily lay hold of my principles. They are elsewhere; in governing, they do so somewhere offside-and yet they can be situated: they are in the text of what I have written on Kafka in the past, although I can find them there only by following directions leading from the place where I am now reading him.

Grasping that it is by means of the present that I am able to discover my principles elsewhere, in the past, I am pained by the pastness, by the already inscribed character of my principles, and hence I am unwilling to find them there. I want to find them here. I do not want to think that I am determined by my past-that in writing on Kafka I am instantiating no new rule, generating no new scheme-and that a Kafka story has failed to open in me an organ of theoretical perception. ${ }^{1}$

I. The historicist and meliorist sides of this reluctance belong, evidently, to the notion of research in the humanities in general and help explain its resistance to a 
Of course, this might be the very point of reading Kafka anew-to def er consciousness of my subjection to past principles of interpretation. And so I will always resist, as disturbing, the requirement of confessing a method: I am not ready; I have not finished reading Kafka; my principles are still forming. I have to advance in the work of specific interpretation before I can shake out the scruples from my shoes.

What emerges as a circle of resistance to confessing principles of interpretation is a variation on the hermeneutic circle, which it behooves me not to get caught in but to get out of in the right way. This means: realize that my principles, wherever they are found, cannot be adequate in advance to the specificity of interpretation, for this is what a text is-the specificity of interpretation; realize that what principles I have can and must be corrected in only one way-by further work of textual interpretation.

These claims evoke some famous disputes and solutions. To grasp that my principles will never be adequate in advance to the specificity of the text is a way of defining what is called the "immanence" of reading. ${ }^{2}$ It is a way of marking literature's independence of the circumstances surrounding its production of meaning, including the intention of the reader and the intention with which an author has endowed his raw materials. ${ }^{3}$ The immanence of literature stresses

structuralist scientism. This is the very attitude that Michel Foucault identifies, in his foreword to the English edition of Les mots and les choses, as constituting the resistance to his enterprise: "The other disciplines . . - - those, for example, that concern living beings, languages, or economic facts-are considered too tinged with empirical thought, too exposed to the vagaries of chance or imagery, to age-old traditions and external events, for it to be supposed that their history could be anything other than irregular." On the other hand, mathematics, cosmology, physics-the "noble sciences" allied with philosophy—are "sciences of the necessary" precisely in not requiring a continual discovery of principle. And yet "[what] if, in short, the history of nonformal knowledge had itself a system?" Foucault means to establish "the laws of a certain code of knowledge" but deplores the association with "structural analysis" (The Order of Things: An Archaeology of the Human Sciences [New York: Pantheon, 1970)], pp. ix-x, xiv).

2. "A literary text . . . merely solicits an understanding that has to remain immanent because it poses the problem of its intelligibility in its own terms" (Paul de Man, Blindness and Insight: Essays in the Rhetoric of Contemporary Criticism, rev. 2d. ed. [Minneapolis: University of Minnesota Press, I983], p. I07).

3. Fredric Jameson, discussing Stanley Corngold, "Kafka's Challenge to Literary History," in Rewriting Literary History, ed. Tak Wai-Wong and Ackbar Abbas (Hong Kong: Hong Kong University Press, I984), pp. 230-3 I. 
instead the completeness with which the work saturates the present act of interpretation. Whatever its genealogy, literature confers on the scene and event of reading a dense, inescapable, local and temporal particularity, making it (writes Manfred Frank) "the critical place where repetition becomes transformation, [proving] the non-simultaneity of the whole of its meaning, the inexhaustibility of its significance," and-stressing now the power of the text to generate an entire succession of readers- "its fundamental ability to be transcended by individuals capable of interpretation." 4 Here we identify at once the literalness of the literary object, its resistance to an extrinsic, generally imputable meaning, and its dependence on the life of the act of interpretation.

As a result, I can never possess the meaning of a text-neither in advance nor as a consequence of a finite act of reading: the text cannot give rise to a completed signifying act. Sartre pointed this out. The literary work, even as it "completes [the life of the author] by expressing it," is transcended by the signifying activity it provokes, which is its project, transforming the author into "a synthetic collection of questions." If a method adequate to the work is regressive, for attending to the circumstances of its origination, it is also progressive, for attending to its power to produce the historical moment in which it is interpreted. ${ }^{6}$ It is, therefore, as a function of its immanence or literality that the work becomes ontologically richer than the author or the epoch that considers it as its project or otherwise appropriates it. ${ }^{7}$ This principle of literalness sheds light on a feature of Kafka's narration. The Metamorphosis is a good example; its narrative struc-

4. Manfred Frank, "Polyvalent Meaning and Nonsimultaneity: Hermeneutical Questions for a Theory of the Literary Text," Sprache und Literatur in Wissenschaft und Unterricht 17, no. 57 (1986): 29.

5. Jean-Paul Sartre, Search for a Method, trans. Hazel E. Barnes (New York: Vintage, I963), pp. I 42-43.

6. Ibid., p. I 54 .

7. Here is Paul de Man's early and eminent contribution to this discussion: "The hermeneutic understanding is always, by its very nature, lagging behind: to understand something is to realize that one had always known it, but, at the same time, to face the mystery of this hidden knowledge. Understanding can be called complete only when it becomes aware of its own temporal predicament and realizes that the horizon within which the totalization can take place is time itself. The act of understanding is a temporal act that has its own history, but this history eludes totalization" (Blindness and Insight, p. 32). 
ture thematizes literal reading. The narrator virtually coincides with the hero, the Aspektfigur; the access that narrator, hero, and reader have to the displaced, uncanny world is restricted entirely to its word-by-word unfolding. In this sense a rapt, immersed reading is the chief action of Kafka's stories, which, as Walter Benjamin noted, can never be exhausted by what is explainable in them. ${ }^{8}$

My second point is that principles cannot be corrected or enlarged except by specific acts of textual explanation. This should suggest the urgency of interpreting Kafka anew, despite the only dim lure offered by a history of readings repeatedly affirming that Kafka cannot be interpreted-an urgency which is favored by the critical atmosphere of the I970s dit "semiotic" but to which, in other respects, Kafka is resistant. In the universe of semioticians in which all entities are signs, all groups texts, and all experience interpretations-in which no self exists, except as the series without paradigm of its readings, and the vale of soul-making has been developed into the archive of soulmarking-Kafka's work would seem to occupy a privileged position because of the rigor with which it holds this view to be deranged. The hero of each of Kafka's novels is, of course, on edge as a being whose main mode of existence is interpretive-who, like the author, is an erschriebenes Selbst, a self achieved through acts of, or like, writing. ${ }^{9}$ But the difference between Kafka's world and "the world of signs" lies in his frustrated sense that the goal even of self-writing is a mode of authenticity, one that would no longer be a mode of reading and would survive precisely when self-enclosed and without signs. The goal gives grounds for despair because, as the prison chaplain in The Trial declares, "the scriptures are unalterable and the comments often enough merely express the commentators' despair" (T 272-73). This means, I believe, that the world is ineluctably scriptural; and every

8. The Metamorphosis thematizes literal reading at the same time, of course, that it indicates its intolerableness. The hero is given the opportunity of a literal reading, which he then rarely takes. What he does see with the intensity of the illusory literal is his "obvious undiscussed assumption" as to what " "stands there." (Martin Heidegger, Being and Time, trans. John Macquarrie and Edward Robinson [New York: Harper \& Row, 1962], p. I92; cf. my Chapter Twelve. At times, it seems, Gregor does rise to the occasion by acting in conformity with the possibilities of his new body; at least the pleasure he has in swinging on the ceiling seems to indicate a sort of joy of reading.

9. Cf. Gerhart Baumann, Sprache und Selbstbegegnung (Munich: Fink, I98I), p. 74. 
comment, having necessarily the form of a wish to escape from this limit, is additional testimony of despair.

Now at this point it might seem wrong to insist that when I read Kafka, principles can never be facts within specific acts of interpretation. They can be, with this proviso: that they are not my principles but the principles of others-of Kafka and, as I shall explain, of his critics. Kafka has inscribed in specific texts of his own the intention that they be self-reflective of literal writing or reading. I base my view of Kafka's intention on these texts and on the principles guiding the other critic with whom I am forever taking issue, even, or especially, as I cite him or her.

I now speak in my own right. My understanding of Kafka's fiction is of an enterprise that aims to engage to the limit the being wholly centered on writing, whose mode is, in Kafka's word, Schriftstellersein, existence as a writer ( $L$ 333). Kafka makes the act of writing fiction the middle of an exploration of a life constituted by the awareness of the exile this imposes and the strength that comes from the sense that this exile is perfect. Aspects of Kafka's project invite eloquent redescription from texts by writers like Roland Barthes, Jacques Derrida, and Gilles Deleuze, for whom writing responds to the (non)origin of articulation, difference, and deferral and for whom literature incessantly figures desire and death as writing. As a consequence, Kafka's social alienation follows from a primordial experience of separation which his relation to writing forced on him (including the separation masked by the simple term "primordial experience"). Social alienation may be a sign of this primary relation, but it is a misleading and factitious sign, because this relation cannot be expressed as a prime origin except "allusively," as Kafka says-through a kind of allegory. A sign more faithful to the fact of separation is "metamorphosis," which is more nearly responsive to the catastrophe confining Kafka's existence to acts of writing, acts of preparation for writing, and acts of interpretation made upon his history as writer. If Kafka captures the sense of his destiny as the crow that dares to storm the heavens, it is by means of an image of the kavka (jackdaw) that inks in, with transcendental expectations, a sky of blank paper. Kafka's old documents, plans, ordinances, mazes, crumbling walls, and castles that merge into villages are forms of the imagination of life lived palimpsestically, in labyrinthine scripts. This dimension of Kaf- 
ka's work is unarguably present-a reflection in the mode of allegory upon existence as writing-and this dimension always requires interpretation because the relation of allegorical sign to meaning is not constant.

At the close of Chapter Three I distinguished between symbolical and allegorical readings of The Metamorphosis. ${ }^{10}$ It followed that there could not be a symbolical representation within a text or a correct symbolic interpretation of a text aiming to constitute Schriftstellersein. Symbolic writing and reading are therefore seduction and error. Kafka's works are essentially nonsymbolic in the sense that their meaning cannot be specified by a scrutiny, however intensified and refined, of their material substrate, of the world of objects- "the face of Nature"-that they represent. For this reason Adorno's reading of Kafka in Prisms is a brilliant error, a tour de force of refined materialist exegesis but a tour de force only, and one that runs counter to the truth of its own premise. For Adorno declares at the outset that the meaning of Kafka lies in the abyss between the literal and the signifying moments of his work, ${ }^{11}$ yet Adorno's actual practice is to find meaning all on the literally material side of the abyss, in Kafka's representations of the detritus cast out by a decaying capitalist order: commodity fetishes, subaltern types, abandoned stairwells, cluttered shopwindows, lumber rooms. Here Adorno is heedless, perhaps, of committing with a vengeance the same heresy of immediate interpretation with which he arraigned the materialist, ideological description of the fetishes of Parisian capitalism in Benjamin's early essays on Baudelaire. ${ }^{12}$ To take up residence, as a critic, somewhere between the literal and the signifying moment of Kafka's images is precisely, of course, to dwell on the incessant moment of disjunction, the ongoing metamorphosis of image as metaphor-or, in a comparable phrase of Benjamin's, on "allegory as script." 13 It is, therefore, to

Io. See further my Fate of the Self(New York: Columbia University Press, I986), pp. I 54-55.

II. Theodor W. Adorno, "Notes on Kafka," in Prisms, trans. Samuel and Shierry Weber (London: Spearman, 1967), p. 246.

I2. Adorno's critique of Benjamin as insufficiently dialectical is discussed in Richard Wolin, Walter Benjamin: An Aesthetic of Redemption (New York: Columbia University Press, 1982), pp. 198-204.

I3. Walter Benjamin, Ursprung des deutschen Trauerspiels (Origins of the German funeral pageant), ed. Rolf Tiedemann (Frankfurt am Main: Suhrkamp, 1982), p. I6 I; quoted in Fredric Jameson, Marxism and Form: Twentieth Century Dialectical Thories of Literature (Princeton, N.J.: Princeton University Press, 197I), p. 72. 
affirm the difference between one's reading as a desymbolizer on the one hand and, on the other, as Benjamin's Grübler- "the superstititous overparticular reader of omens" in the allegorical world where things are "sundered from meanings, from spirit, from genuine human existence" (thus Fredric Jameson). ${ }^{14}$ Benjamin writes:

Once the object has beneath the brooding look of Melancholy become allegorical, once life has flowed out of it, the object itself remains behind, dead, yet preserved for all eternity; it lies before the allegorist, given over to him utterly, for good or ill. In other words the object itself is henceforth incapable of projecting any meaning on its own: it can only take on that meaning which the allegorist wishes to lend it. He instills it with his own meaning, himself descends to inhabit it, and this must be understood not psychologically but in an ontological sense. In his hands the thing in question becomes something else, speaks of something else, becomes for him the key to some realm of hidden knowledge, as whose emblem he honors it. This is what constitutes the nature of allegory as script. ${ }^{15}$

"Script rather than language," adds Jameson in his gloss, "the letter rather than the spirit. . . A Allegory is the privileged mode of our own life in time, a clumsy deciphering of meaning from moment to moment, a painful attempt to restore a continuity to heterogeneous disconnected instants." 16

And yet, as evocative as Benjamin's text is of Kafka's readertransfixed, say, by Odradek, by the torture apparatus, the castle tower, or the obscene scripture of the court-it is incorrect in its tendency to kill the object, to make it the empty cipher of the brooder's intent: these objects reflect back on the linguistic energy that propels them into existence as the fictive imagings of metamorphosed metaphors torn from context, from the stability of ordinary narrative. Jameson's gloss, though it was never intended to apply to Kafka, would make Kafka's narrative too much the project of recovering a genuine human life of the middle, where Kafka's narrative is concerned above all with enacting the necessary consequences of writing. This is to emphasize the randomness of empirical existence and also to conjure with an existence anywhere out of this world.

In having now evoked the work of some of Kafka's best critics, I

14. Jameson, Marxism and Form, p. 7I.

I s. Benjamin is quoted in ibid., p. 72.

I6. Ibid. 
conclude by affirming my admiring quarrel with them. I stand in a relation of apparent opposition to but real dependency on Kafka's interpreters, whom I am swift to accuse of having bad principles. ${ }^{17}$ "Opposition," because the principles they assert are not radical enough for the centrality of writing in Kafka, but "dependency," too, because my principles are won antithetically from the specific insights of these critics-by the impression of correct insights arising from their momentary disregard of principle, and by the freedom that their mistakes, arising from their fidelity to insufficient principles, engender.

Let us look at the achievement of one of the best of these critics.

I7. For a statement of some further disagreements with the implications of Adorno's and Benjamin's work on Kafka with respect to Metamorphosis, see my Commentators' Despair (Port Washington, N.Y.: Kennikat Press, 1973), pp. 5I-53, 76-77. 


\section{Chapter Twelve}

\section{"The Pure Expression": An Exemplary Reading of Kafka}

Jörgen Kobs, a young Germanist at Tübingen, died in an automobile accident in I968, leaving behind the manuscript of his only book, Kafka: Untersuchungen zu Bewußstein und Sprache seiner Gestalten (On the consciousness and language of his characters). ${ }^{1}$ The text was revised for publication in 1970 by Ursula Brech. Her decision was more than an act of piety, for Kobs's book is masterly. The plan to rescue a critical work of such originality, accuracy, and radiance, and in this way bring Kafka's work to light, is not strictly incomparable with Max Brod's original salvaging project. Kobs's philosophical devotion to his subject, seen in the perspective of his early death, recalls the strictness, fragility, and tension of Kafka's literary enterprise.

In the wake of Kafka's mythographers and iconographers came his structuralist critics. His recent canonization as an author of handbook rank and as the object of a critical edition-while certainly a fate his importance merits - tends further to hypostatize the act by which his work arose. Kobs's book and Kobs's death renew a sense of frail energies concentrated on metaphysical design: that of elaborating a language able to analyze life into its visible parts, in order to contend with it and "raise it up" (DII I 87). ${ }^{2}$

I. Jörgen Kobs, Kafka: Untersuchungen zu Bewußtsein und Sprache seiner Gestalten, ed. Ursula Brech (Bad Homburg: Athenäum, 1970). Quotations from this work are indicated hereafter by page number.

2. 'I can still have passing satisfaction from works like 'A Country Doctor,' provided I can still write such things at all (very improbable). But happiness only if I can raise the world into the pure, the true, and the immutable" (DII I87). 
Kobs's study, 560 pages long, is the most important panoptic book on Kafka since the works of Emrich, Sokel, and Politzer. ${ }^{3}$ It may be the most productive of them all because, apart from its discoveries about Kafka's fictional world, it is exemplary for its method. It exhibits the practices grounding the best work on Kafka of whatever ideological kind. Kobs's studies of the manuscript of Kafka's "America-novel"- which Kafka referred to as Der Verschollene (The boy who was never again heard from)-demonstrate, first, the importance of the most exact efforts at establishing Kafka's texts even where the changes are ostensibly few and slight. Kobs can draw astonishingly rich conclusions from the faint variations constituting the authorial history of single phrases, even single participles. His philological intensity supplements Emrich's, Politzer's, and Sokel's high classical interpretive style while proving decisively the need to undo Max Brod's editorial intrusions. If now, in 1988 , we have a fair text of Amerika, thanks to Jost Schillemeit's work on the new critical edition, it is in good part due to the impulse coming from Kobs's book. ${ }^{4}$

Equipped with an authoritative text, Kobs follows his main principle: intrinsic, "work-immanent" analysis. He examines the semantic implications of variations in word order and types of diction as they emerge from trial transformations of Kafka's sentences. ${ }^{5}$ Kobs's data

3. Wilhelm Emrich, Franz Kafka (Frankfurt am Main: Athenäum, I965); Walter Sokel, Franz Kafka: Tragik und Ironie, Zur Struktur seiner Kunst (Frankfurt am Main: Fischer Taschenbuch, I983); and Heinz Politzer, Franz Kafka: Parable and Paradox (Ithaca: Cornell University Press, 1962). Along with Kobs's book, Gerhard Kurz's recent Traum-Schrecken: Kafkas literarische Existenzanalyse (Stuttgart: Metzler, 1980) must now be reckoned a synoptic work of great distinction.

4. Kobs's work deserves credit for having helped make urgent the sense in the last decade that a critical edition of Kafka's works could no longer be postponed. Two volumes have so far appeared from Fischer Verlag, Frankfurt am Main: Das Schlo $\beta$, ed. Malcolm Pasley (I982), and Der Verschollene [Amerika], ed. Jost Schillemeit (1983).

5 . "Simply by the manner in which a speaker arranges the various parts of a taxeme [a sentencelike element], by which he structures their succession within the possibilities of variation at his disposal, he reveals distinctions of interest, says (wholly explicitly) what seems significant and what seems less important to him" (p. 350 ). Kobs's tool for his analysis of the semantics of syntactical variation in sentences comes from the linguistics of Hans Glinz. Kobs's procedure can be viewed as part of the modern project, following Barthes, to reimagine two other senses of the linguistic sign apart from the symbolic-apart, that is, from the alleged power of signs to represent immediately the substance of their meaning. These two other senses are the syntagmatic (the sign is grasped in the linear context of its grammatical arrangement) and the paradigmatic (the sign is grasped as the object of a selection made from among 
are the minimally interpreted semantic correlatives of structural anomalies in Kafka's grammar and diction. This analysis presupposes and, by its results, proves a major premise: that Kafka's texts reward scrutiny of the most microscopic nuance, each increase of optical intensity producing an increase in the depth of penetration. It becomes entirely improper to think, for example, that Amerika can be read with something less than exhaustive fidelity to word order on the putative grounds that it is af ter all an imperfect text never intended for publication. Kobs's "Amerika" text is genuine in two senses: it is philologically reliable, and it is also a kind of absolute-an authoritative constitution of worldly consciousness, perfect for what it has left out as much as for what it includes, wider and deeper than Kafka's previous commentators, however patient and ingenious, have imagined. ${ }^{6}$ It is no mean sign of Kobs's genius that he is able to dwell for over a hundred pages on some thirty sentences from Amer$i k a$ and not be boring. The extraordinary demand he makes on the reader is lightened by the fluency and clarity of his exposition.

Kobs's main concern is to define the distinctive "way of seeing" (Sehweise) produced by the form of Kafka's sentences. This is, in a strict sense, the same project as describing the world of Kafka's main character without the help of categories furnished by the extraliterary systems that Kafka deplored (for example, psychoanalysis). How can the link between his world and the distinctive verbal structure of his vision be made so direct? That is because the world of Kafka's fiction is constituted entirely by perception identical with that of the hero's. "Everything," writes Kobs, "that is narrated and described is seen from the perspective of only a single person," even where there is no explicit signal that this is the case. "Only the thoughts of the main character-not those of other characters as well-can be represented; only those events can be reported at which this person-seeing, hear-

a group of substitutable congeners). For a brilliant reading of how Faust's Bible translation "suspended for a century the sign's assignation to the groups of which it is an element," see Friedrich A. Kittler, Aufschreibesysteme 1800 . 1900 (Munich: Fink, I985), p. I9.

6. On the matter of the literary work's being perfect for what it keeps silence about, unlike the work of criticism, see Joel Fineman's "The Structure of Allegorical Desire," in Allegory and Representation: Selected Papers from the English Institute, (Baltimore: Johns Hopkins University Press, 1983), pp. 49-50, 58. 
ing, feeling, and thinking-is present" (p. 25). Kobs's analysis of perspective therefore addresses itself to the whole world of the novel, for in Kafka the verbal texture is the fictive world. In following the assigned forms of consciousness of the hero-narrator, Kobs defines the structures of his worldly experience. The hero's actions issue selfevidently from his way of seeing the world; an account of them can be given without recourse to the universalizing, material motivations supplied him by the exegete (read psychoanalyst). ${ }^{7}$

This is Kobs's enterprise, and I think it succeeds beautifully, in the sense that I can always either consent to what he writes or else feel that it opens up only the advanced form of an enigma. Kobs shows that the principles of the world of Kafka's hero are indeed the a priori forms of his apperception. He uncovers these principles in detail. $\mathrm{He}$ shows that they cannot be situated at the level of the hero's material intentions in combat with the supposed norms of an impersonal alterity- with our nature or society or law. Hence naturalistic interpretations of Kafka's characters, like those of empirical psychology, are at best speculative. ${ }^{8}$ In this order of explanation, as Heidegger puts it, "one is appealing to what "stands there" in the text only in order to assert "one's obvious undiscussed assumption." 9 The categories that Kobs addresses, however, are necessary, being linked to language: they constitute the world of Kafka's heroes.

But the special value of Kobs's procedure is more than its wider economy-its generality and coherence-as a method of reading Kafka, supposing, as I do, that his minimally interpreted semantic correlatives do indeed go beyond special pleading. The gain is more

7. Kobs insists on another fundamental peculiarity of Kafka's narration that looms large in his findings: Kafka never interpolates future occurrences; the narrative perspective is rigorously confined to the present moment. The utterly unique distinction of Kafka's method is not Einsinnigkeit, the so-called coincidence of perspective as between narrator and perspectival figure, but the form of the experience of timestrict linearity, the series of empty and incandescent present instants.

8. Is Gregor Samsa, e.g., a subliminal malingerer and family avenger? Certainly the verbal reality of the work is strikingly bare of named intentions, wishes, motives-conscious or otherwise. The Metamorphosis is short on wishes apart from the wish to go under (i.e., to have no wishes). Still, this is not the worst hypothesis. Yet in illuminating certain cruxes, psychoanalysis muddles others: e.g., how can the unconscious wish to be at once aggressive and submissive account for the specific kind of enjoyment that Gregor finds in his sister's violin playing?

9. Martin Heidegger, Being and Time, trans. John Macquarrie and Edward Robinson (New York: Harper \& Row, I962), p. 192. 
than the articulation of Karl Rossmann's, Joseph K.'s, and K.'s way of seeing. What is at stake is the question of whether or not one can admit into Kafka's fictive world the possibility of an edification of persons. In naturalistic readings-whether psychoanalytic, Marxistic, aesthetic, or Bildungs-philosophical-Kafka's world is in principle redemptive. That is because these systems, in advancing the superiority of one type of worldly experience over another, have in common a belief in the truthfulness of experience. It follows that just as Kafka's critic at home in natural experience fulfills his or her life through a dismantling of illusions, perceiving with relief the merely delusory sovereignty of the reality that torments him or her, so too Kafka's hero can in principle be redeemed, on the condition that he or she too have the benefit of this training in critical reason.

In Kobs's account, however, there is no (or almost no) possibility of liberation from the a priori constraints on any consciousness that interprets. "As subjectivities," he writes, "Kafka's characters are always already in a state of self-alienation" (p. 4II). "To be a subject means just this: to live outside all positive existential definitions, to exhaust oneself in abstract, hence absolute, yet groundless claims" (p. 387). There is no way-none, at least, leading through social experience, through the mutual interpretation of subjectivities-for characters in Kafka's world to arrive at the center of their personality. (I shall explain shortly why I qualify this point by writing, above, "almost no possibility of liberation" and, now, "no way-none, at least, leading through social experience.") An initial, ineluctable obstacle prevents even a rudimentary hearing, so that revelation through another of the hidden, equivocal, yet propulsive images of oneself is a priori reduced to confusion by the intrinsic shortcomings of interpretative consciousness.

But much worse: the mutual relation of all subjectivities tends actively not toward attempts at illumination but toward annihilation. "Because they are subjects, consciously active beings intentionally directed toward objects, they simply cannot avoid pushing their opposite number further and further into the background, restricting his possibilities, robbing him finally of any sort of free play. . . . In these novels there is actually no possibility of avoiding the turnabout of altruistic strivings into the absolute egoism of subjective being" ( $p$. 3I 5 ). 
What, then, are the typical, indissolubly mediating forms of, say, Karl Rossmann's “subjective consciousness"? Kobs describes them as

the projection of his own inwardness onto the outer world; his unmotivated distrust, which robs itself of its own foundation; his translation of coincidence into causality; his tendency subsequently to seize on impressions having an only subjective validity, as if they were objective facts; finally, his inability to arrive at consistent observations and to interpret his observations without contradiction. . . As soon as Karl attempts to verify his subjective fore-conception against the concrete situation, he becomes captive of the situation. . . . The concrete case, which is supposed to confirm the general, to lend it visibility and weight, in fact makes it dubious and uncertain. [pp. 47, I32-35]

Karl's troubled seeing, slightly modified, appears again at the beginning of The Castle as the failure of the project of determining essence, the inadequate overview, the observer's slide into detail, the distorting effect of minute observation:

The world that appears to the observing subject as the indifferent contiguity of isolated parts cannot, . . . even through superior acts . . . of relational thought and judgment, come to light as a meaningful and structured totality. Of course, relational thought establishes distinctions of rank, but the connections it is capable of generating always remain "short-circuited." Of course, the subject, in judging, takes up a position ....: it establishes gradations among values ...., but the engagement that every act of judgment presupposes necessarily misses the object to be judged and leads to the self-negation of the judger, leads back, therefore, into indifference. [p. 350]

Now if Kobs's achievement were simply the discovery that Kafka had revealed the constitutive activity of the subject, then Kobs would have discovered the North Pole for the second time. And if he were to argue only that Kafka's account of his characters' way of seeing always aims at the fundamental nature of cognition and judgment in any consciousness, then neither his nor Kafka's achievement would be decisive. Kafka would be functioning as epistemologist, hermeneut, and philosopher of intersubjectivity without different or deeper effect than, say, Nietzsche. Kobs's power in fact lies elsewhere: in his ability to develop the radical bearings of Kafka's epistemological concerns on the meaning of his fictions, and to turn these principles-an instructive scourge-on Kafka's heedless interpreters. 
He shows, for example (on the basis of a chapter fragment from the body of Castle manuscripts) that Kafka's heroes are never so isolated and outcast in a world not of their making as they, and Kafka's critics, are inclined to suppose. These readers take the subjective impressions of characters as if they were objective givens.

In fact all subjectivities are alike in their ignorance. The village inhabitants understand $\mathrm{K}$. and themselves exactly as little as $\mathrm{K}$. could understand himself or them. . . . [Here is an initial statement] of the general identity [for Kafka] of all figures who experience the world through the mediation of their consciousness. . . . It is the equivalency [GleichGültigkeit] of all events which makes Kafka's world seem not only indifferent to values but strange and unintelligible. The perspectival determinant of permanent alienation can be recognized only in the continual incongruencies and contradictions that run through the ostensibly precise observation. [pp. 198, 205]

In this light it becomes impossible to construe a contradiction that the hero registers within his conscious horizon as the collision between a fact and a mere surmise. Kafka's heroes are not, as is of ten said, forever tarrying in the domain of pure possibility: K., for example, is constantly at work erecting pseudorealities around him, and it is interesting for him to do so.

When, now, Kobs attempts to grasp the meaning of Kafka's work as a whole, he cannot escape a fundamental enigma. The main outline of his reading is clear: he sees Kafka's fiction as a flow of intentional energies. The poetic will aims to extract from itself and-via the exemplary reduction and schematization of this extract-to create a model of inauthentic, appropriative, striving, ultimately self-devouring consciousness. Kafka remains pure as his work acquires the purity of total but perfectly organized error. ${ }^{10}$ "Total" error? This is the

Io. This could be the place to stress the way in which Kobs's view surpasses Heinz Politzer's account of the paradoxical character of cognition in Kafka's heroes. In Franz Kafka: Parable and Paradox, Politzer wrote incisively about Kafka's paradoxes, and indeed Kobs draws on him. But Kobs's work is different by virtue of its stringently antipsychological thrust. Politzer's conception of paradox has a wide, impressionistic governance, whereas Kobs defines and develops Kafkan paradox as a strict circle of contradiction on the model "A Cretan says, "All Cretans are liars." "In this neutralization of tendencies [both toward and away from signification]," writes Kobs, "in the opening up of the hermetic circle, through a movement which itself leads to a void of indeterminate content, lies the real difficulty in understanding Kafka's works" (p. I 8). The paradoxical circle introduces, most visibly into the shorter prose, a structural 
problem. Kobs's account wavers at this point. Consider the following exhibits (italics throughout are my own):

I. Concerning the process by which subjectivities engaged with one another move toward mutual annihilation, Kobs writes: "Although it is nothing but a phenomenon of consciousness, still the engaged subject cannot himself in any fashion understand it or be made conscious of it" (p. 336).

2. "For Kafka's figures, who never reflect on the role which their own consciousness plays in the act of understanding, the hermeneutic circle remains a circulus vitiosus" (p. 420).

3. "Everything narrated was able to be narrated the way it was narrated only as mediated by Karl's consciousness. . . . The principle of congruence means that all depicted events appear only as mediated by a subjective consciousness" (pp. 32-33).

Hence the truth freed by the confinement and reduction of inauthentic consciousness to its own basis could never in this novel be portrayed in itself but only as it appeared for Karl: hence, as untruth.

But consider another series. This series turns on a key term in Kobs's argument, "the pure expression [der reine Ausdruck]." The axial point in Kafka's heroes' way of seeing, at which a hypothesis about experience collapses into blank facticity, is a Leerstelle, a void for any consciousness, which nonetheless-for Kobs-conceals and shelters a fundamental reality. This reality can actually be experienced, however, by the character who gives himself up to his pure expressive response to it. The pure expression may be a mute gesture: "Nowhere... does experience find a purer expression than in the spontaneous unmediated gesture" (p. 4I2). Or it may be a fit of weeping like that, for example, of the desperate observer of " $U p$ in the Gallery," who cannot fuse what he sees with what he imagines. "The pure expression," continues Kobs, "actually does break through the covering and masking strata of subjective overlays and reaches

principle of indeterminacy. It has the same effect as the principle of narrative congruence in the novels-a principle that operates the reduction to an immediate present and hence to the inescapable mediation of all events within the novel by a subjective consciousness. The rigorous correlation in Kobs of novelistic detail and fundamental interpretation closes gaps in Politzer's intuitive "psychological" speculations. 
down to the basis of reality: indeed, it radiates authentically from this basis. Exactly for this reason the pure expression must remain a great rarity in Kafka's work, in a world that is mediated by the principle of the way of seeing" (p. 40I). It is a tribute to Kobs's scrupulousness and mastery of the whole of his argument that in the very act of introducing the category that unsettles it, he alerts the reader to the danger. For in the light of the preceding account of Karl's way of seeing, the pure expression cannot be "a great rarity"; it cannot exist at all. "Pure" reality cannot come to light within a work systematically mediated by inauthentic consciousness.

Kobs's discussion of this point only adds further difficulties. Describing Karl's response-his interpretative restraint-in the face of pure expressions by Robinson and by Karl's uncle, Kobs writes: "Precisely because Karl Rossmann stays completely outside the matter as an interpreter [schaltet sich auf keine Weise deutend ein], he succeeds in making visible reality transparent. .. . Instead of getting involved in interpretation, instead of weighing the external as the expression of the internal, he follows as attentively as possible only the visible events, and thus he succeeds in uncovering the basic pattern of all social acts" (pp. 40I, 403). This basic pattern is tyranny.

How, then, can it be true (as Kobs writes) that the pure expression so described "signifies [bedeutet] nothing despite its abundance of meaning [Sinn]"? Can it "signify" nothing while disclosing the "basic pattern of all social acts"? The pure expression amounts for him who performs it to a "gratifying and liberating unity of external and internal, of phenomenon and meaning" (p. 4I2). Merely in "following the phenomenon attentively," Karl Rossmann brings "the inner meaning" of the gesture to the surface as significance. But significance (Bedeutung) is precisely what belongs to the object of interpretation (das zu Deutende). Hence the distinction vanishes between Karl's customary interpretative way of seeing, which looks for significance, and the rare suspension of perspective, which here discloses significance. Once the absolute prerogative of Karl's way of seeing has disappeared, Karl's experience can in principle be read at all times either as a distortion of reality or as itself the gesture disclosing a deeper reality - "a unity . . . of phenomenon and meaning"—such as social facticity.

Now Kobs insists that Karl does not himself grasp the significance 
that he brings to light. The inauthentic consciousness remains sealed off from truth. But in order to have Karl succeed in bringing out the "basic pattern of all social acts," Kobs has had to suspend the mediating activity of Karl's ordinary conciousness. The seal is ruptured. Karl's consciousness can be stopped long enough for him to bring to light "the authentic basis of reality"-but if this is so, then there is no reason in principle, no argument possible, to prove that $\mathrm{Karl}$ is unable to grasp the significance of his act.

The notion of the pure expression therefore produces at least these difficulties: How, in Karl's world, could a perspective be entirely neutral with respect to an object-an expression? How could Karl's failure to interpret the expression uncover its significance? How could a unity of sign and meaning appear within the degraded language of this fiction: that is, how could an object that Karl names appear as it is, without disfigurement?

Through these contradictions an even more fundamental one arises: that of the status of represented consciousness in the novel-of Karl and, hence, of the narrator. At the outset Kobs writes that Karl "cannot succeed in attuning to one another" the various determinations of his judgment (p. 124). But now Kobs has Karl succeed in suspending his interpretative interests for the sake of his object. Clearly, it is not in Karl's power to decide when to succeed and when not to; the decision lies outside him. But neither is this decision arbitrary. Here is the difference between a fiction and reality. Whether a consciousness sees truly or falsely is, in a fiction, the responsibility of another consciousness.

Another consciousness? The absoluteness of congruence as a narrative principle is now jeopardized; the perspectival figure stands in critical relation to a narrator who is responsible for his success or failure, who decides when to suspend the optic of Karl's inauthentic consciousness. The gap that the "pure expression" broaches in the narrative of the novels invites further destruction of its unity. To a putative narrator-for Kobs "the narrator to be postulated" (p. 32)now belongs the wider consciousness responsible for fundamental decisions of composition. It decides when and with what effect Karl Rossmann's consciousness splits, turns in on itself, and perfectly betrays its designs. It elects one kind of material substrate in Rossmann's "mere impressions" rather than another, knows the meaning 
of certain bookish allusions within the text that Rossmann is unlikely to know, exists as the reticent awareness of the horizon of meaning within which individual moments are situated. There is a narrator perceptible in Amerika, despite the congruence of one dimension of his consciousness with that of the main figure. Kobs is wrong to assert that "it can therefore no longer be said that the narrator says something, gives us to understand something, for he is reduced to the function of a merely registering organ" (p. 32; my italics).

Kobs does indeed grant the presence of a superior consciousness flowing around Kafka's work. He speaks explicitly of "the writer's intention" (p. 258). "The alleged presence [in Karl's world] of a comprehensive horizon of observation is ironically distanced by the writer" (pp. 22I, 284). "The writer treats his creation with irony" (p. 255). But Kobs eschews the identification of this superior consciousness with a work-immanent narrator. "It must be stressed once again that there is no superior narrator in these stories who could bring to light his own thought-forms . . . behind the characters' backs" (p. 302).

The key word is "in," "in these stories." Kobs wants the superior consciousness to be wholly outside the novel. A wholly truthful authorial consciousness must exist outside the work, keeping itself pure at an "ironic distance"; the work itself exists as the dross of the act of writing. Kobs's model is binary: the writer remains truthful; the work exists as hermetically schematized monological error corresponding to Kafka's "real [i.e., empirical] self." But this model is destroyed by "the pure expression," which postulates a narrator inscribed within the text who is not identical with "Kafka the writer."

If Kobs's scheme were genuinely intrinsic or work-immanent, he would be required to cede the binary division of consciousness to one asymmetrically triangulated. His reading is in fact founded on a doctrinal view of Kafka's intention drawn from the confessional writings, which does not deliver the most adequate or interesting theorem. The mediator of the fictive world of Amerika is not Karl Rossmann but a narrator only one side of whose consciousness is congruent with Karl Rossmann's and whose other sides set Rossman in a different perspective. The degree to which this different perspective is explicit and visible varies from moment to moment, but it is active even in the moments when it is least perceptible. The work is 
thus at all times a play of the narrator's presence/absence; the character of the fiction is at all times equi-vocal, for the degree of presence/ absence of the narrator's voice belongs to the novel as part of its total interpretation. I stress "interpretation"; the reader has no certain guide. It does not follow, for example, that the work is most truthful when the narrator is most visible, for the explicitness of his presence runs counter to the degree of presence with which, following Kobs, the pure expression could come to light. But neither, of course, is the narrator's apparent absence a guarantee of the truth of the gesture. Indeed the work is dominated by the phenomenon of the apparent absence of narrator and the presence of sheer error.

If, then, the felt presence of the narrator is no guarantee of the truth of the action, it follows that in one important sense the narrator is not reliable. Irony in this work does not flow all one way, from the superior narrator to the deluded hero; in the moments when the narrator merges his perspective with that of the hero for the sake of the pure expression, the hero celebrates an ironical (because unconscious) victory of captivation over the narrator. In such moments the narrator suspends the limitations of the hero's perspective, cedes to the hero the prerogative of his own vision. And yet for what does he relinquish his own sobriety, lucidity, and sense of self? Is not the very temptation of pure expression in the world of the K. $\mathrm{s}$ a delusion and a snare?

Kafka's narrator (pace Kobs) has to be seen as in a condition neither of truth nor of error but at once of truth and error. His condition mingles stupidity and insight inextricably. But this mingling should not imply that in the narrator both dimensions are reconciled into a unity-certainly not, at any rate, the "unity of contemplativeness and activity [which] exists only in the congruence of narrator and perspectival figure, in the personal unity of 'writer' and 'real self'" (p. 539). The relation of truth and error in Kafka's perspective is not continuous but "allusive"- the allegorical language of allusion meanwhile implying a division between meaning and phenomenon and, more, division within each meaning and each phenomenon.

As a consequence of this state of affairs, it is impossible to decide authoritatively whether at any given moment the language of Amer$i k a$ is to be read literally, as accurately presenting Karl's own erroneous grasp of the world, or figuratively, as proffering Karl's experience 
as pure expression, as a gesture whose truth undoes the manipulative, "ironically distancing" perspective of the narrator. This zone of indetermination in Kafka - which Kobs, albeit inadvertently, leads us to discover-appears to be the ultimate field of Kafka's paradox.

\section{Postscript}

Earlier, in the conclusion to Chapter Ten, I spoke of a moment of "unity" in Kafka-an ecstatic movement of critical activity and contemplation. The form of such a movement is defined in the Octavo Notebooks as "the activity radiated by contemplation, or rather, that which returns to it again" (DF 97). Such movements follow the death or virtual death of the heroes of "The Judgment" and "The Burrow" after their will to maintain and reify metaphors has been destroyed. A moment of unity is also present in the fusion of contemplation and critical activity that excoriates the bachelor's frozen fear in "'You,' I Said ..." or dissolves Joseph K.'s false hold on life in The Trial.

Are such moments to be thought of as experiences for a reader? If so, they would indeed close off the field of Kafka's paradox. Yet if they exist, why, then, in the preceding pages, have I taken Kobs to task for affirming moments of unity?

The reason is that our conceptions of Kafka's privileged moment are not actually comparable. Consider the kind of unity that Kobs sees represented in Kafka's work. He speaks of a fulfilled "unity of contemplativeness and activity [that] exists only in the congruence of narrator and perspectival figure, in the personal unity of 'writer' and 'real self'" (p. 539). I cannot agree, however, that Kafka situates such a moment on the level of a narrator congruent with his character. It is equally difficult to envision a moment in Kafka's work bringing about a personal unity of the writer and the real self. If such a "pure" yet articulated "expression" exists, it would have to be attributed to Kafka as narrator, occurring in the instant at which his congruence with his character dissolves. Indeed, in his diary, Kafka identifies the high moment of his art as one following the enactment of a character's death and consisting in the narrator's lament that "dies [verlaufen] beautifully and purely away" (DII I02; Ta 449).

The truth of unity is certainly not in the pure expressiveness of scenes of dying. Admittedly, Kafka exalts them in saying that they 
are "secretly a game" for the writer, who means to "lie very contentedly on [his] deathbed" and who consequently has "a much clearer understanding" of death than the distracted sufferer or reader who suffers with him. The writer's distance allows him to "rejoice in [his] own death." Yet such a rejoicing suggests that even as Kafka describes the dissolution of congruence, he is prey to insidious forms of inauthenticity. For the condition of his rejoicing is his character'ssomeone else's-death. And it is not proved that the empirical person Kafka possesses the "capacity . . . to meet [his own] death with contentment" (DII I02). ${ }^{11}$ It is only the lament, the radiant passage from the "critical activity" of death to its contemplative recovery, that is "true" (DF 97)-a moment that cannot be called "the personal unity of 'writer' and 'real self." In one sense the writer cannot die, for "he is already dead"; in another, the notion that his body will die contentedly is only a hopeful surmise. That death is beautiful, says Kafka, in which the lament dies purely away; neither Kafka's nor any reader's real death is beautiful.

It follows, therefore, that the moment of radiant contemplative activity in Kafka's work is not one that could be experienced by one empirical personality on the strength of another's or instituted by a reader as a source of strength to which he or she could return again and again. These moments arise from acts of dissolution, graspable only as they themselves dissolve into the task of being contemplated. Thus, their radiance is only virtual, like "the radiance that fell from Ulysses's great eyes"; but "if the Sirens had possessed consciousness, they would have been annihilated at that moment" (GW 250). The "truth" is the barely heard music of dissolution, of the death of an illusion that returns to thought. But death is "clearly understood" only in a world already raised into "the pure, the true, and the immutable" (DII I 87). If writing gives glimmers of such an understanding, it is, as Kafka said, "only . . . allusively" (DF 40)-that is, by means of the destruction of familar metaphors. This destruction gives rise to new metaphors worthy of dissolution; that is the necessity of form.

II. See Chapter Five. 